\title{
On the Torgud (Kalmyks of the Volga Region) Banner in Western Qalqa during the Middle Years of the Yongzheng Reign (1728-1731)
}

TSONGOL B. NATSAGDORJ

Mongolian Academy of Sciences, Mongolia

Volume 13, 2015

As the result of the first Qing-Dzungar confrontation at the end of the 17th century, different Oyirad groups were incorporated into the empire. This essay discusses one Torgud (Kalmyk) jasay-banner among them, which, unlike its better-known counterpart on the Etsina River, has remained virtually unknown to scholarship. The Qing government, hoping to ally against the Dzungars with the Kalmyk-Torgud polity in the Ural-Volga region, offered favorable treatment to Torguds who entered its territory. The formation of this second, little-known Torgud jasay-banner was a manifestation of this policy. However, this policy failed when the strains of war caused their loyalty to fellow Oyirads to overcome that owed to the Qing government.

论雍正中期西喀尔喀蒙古的土尔扈特部（伏尔加地区的卡尔梅克人）

(1728-1731)

Tsongol B. Natsagdorj 那楚克道尔吉

蒙古科学院

十七世纪末清朝与准噶尔部之间的首次战争，使得卫拉特蒙古的 诸多部落并入了大清帝国的疆域。本文将讨论这些部落中的土尔扈特（卡尔 梅克）札萨克旗; 有别于著名的额济纳流域的土尔扈特部, 这支部落在学术 界迄今无人提及。为了联合乌拉尔山一伏尔加河地区的卡梅尔克一土尔扈特 政权共同对抗准噶尔部, 清朝政府向进入其疆域内的土尔扈特部提供了优渥 的待遇。这支鲜为人知的土尔扈特札萨克旗的形成, 即是清廷该项政策的产 物。不过, 当战争的压力使得他们对卫拉特部同胞的忠诚压倒了对清廷的忠 诚，这项政策最终宣告失败。 
論雍正中期西喀爾喀蒙古的土爾扈特部（伏爾加地區的卡爾梅克人）

(1728-1731)

Tsongol B. Natsagdorj 那楚克道爾吉

蒙古科學院

十七世紀末清朝與準噶爾部之間的首次戰爭，使得衛拉特蒙古的諸多部 落並入了大清帝國的疆域。本文將討論這些部落中的土爾扈特（卡爾梅克） 札薩克旗; 有別於著名的額濟納流域的土爾扈特部, 這支部落在學術界迄今 無人提及。為了聯合烏拉爾山一伏爾加河地區的卡梅爾克一土爾扈特政權共 同對抗準噶爾部, 清朝政府向進入其疆域內的土爾扈特部提供了優渥的待 遇。這支鮮為人知的土爾扈特札薩克旗的形成, 即是清廷該項政策的產物。 不過, 當戰爭的壓力使得他們對衛拉特部同胞的忠誠壓倒了對清廷的忠誠, 這項政策最終宣告失敗。

When the Qalqa noblemen submitted to the Kangxi emperor in 1691, the Qing empire incorporated most of the eastern Mongols of the so-called Six Myriarchies of the time of Batu-Möngke Dayan Qayan. As a result, the Qing empire was now bordered by the Dzungar state on its northwestern and western frontiers. Once he had defeated Galdan, Kangxi immediately set about incorporating the Dzungar state, now headed by Tsewang Rabtan Joriytu Qungtayiji, and armed conflict ensued. O. Oyunjargal's recent Manj Ching ulsaas mongolchuudyg zakhirsan bodlogo has described the Qing empire's policy toward the Dzungar state and the roles played within the Qing empire by the submitted Oyirad groups formerly under Galdan and by the relatives of the Khošud Očirtu Sečen Qayan. Among these populations incorporated into the Qing empire was even one group of Torguds from the Volga region, who were organized by the Qing into a banner ruled by a jasay and later settled along the Etsina River. But there was also another banner of Torguds from the Volga region that remained in western Qalqa during the first years of the Yongzheng emperor's reign. What follows is an analysis of these latter Volga Torguds.

\section{The Torgud Gomang Lama Dondub Gyatso (?-1710)}

Among the holdings of the Mongolian National Central Archives related to the Küriye amban and the Uliyasutai governor-general, there are fragmented documents, particularly correspondence between the vice-general of the Qalqa left wing Doroi efu Dan- 
zandorji and General Basai, dating from Yongzheng (YZ) 10 (1732). Their letters concern this western Qalqa Torgud banner and the nearby Oyirad banners and the Qalqa banner of the Duke Tongmok in the Jasaytu Khan Ayimay. From these documents we learn that their tayijis were relatives of the Torgud Ayuki Khan's Gomang Lama. ${ }^{1}$

In the historical literature, we find hardly any information about this Gomang Lama. There are just a few written sources about him: the "Crystal Mirror" by Tugan Qutuqtu Lobsang Choikyi Nyima, ${ }^{2}$ the Biography of I Jamyan Shadba by Gonchok Jigmed Wangbo, ${ }^{3}$ and the biography of the VI Dalai Lama Tsangyan Gyatso. ${ }^{4}$ Based on these sources, there are brief mentions of Gomang Lama in studies by Ge. Lijei and L. Terbish, and from these we can sketch an outline of his life.

Dondub Gyatso was born to aristocratic family among the Volga Torguds and studied at the Dashi Gomang within the Drepung monastery in Lhasa. In 1673 he was elected as the twenty-ninth abbot of Dashi Gomang and served in this position for three years. For this reason, he was known more as Gomang Lama ${ }^{5}$ than as Dondub Gyatso. ${ }^{6}$ After retiring as abbot, Gomang Lama returned to the Volga steppe and actively spread Buddhism among the Torguds. He then came back to Tibet in 1704 and made many offerings to Lhasa monasteries, after which he was appointed abbot of Litang Monastery. In 1708 he was still residing there, preventing the deposed sixth Dalai Lama Tsangyan Gyatso from visiting there for more than three days. After his death (his dates of birth and death are both unknown) he was reincarnated, and the residences of subsequent reincarnations of Gomang Gegen were all located among the Qarašar Torguds of Xinjiang province. ${ }^{7}$ The addition of further sources makes possible an even fuller picture of Gomang Lama Dondub Gyatso's political life.

We have already seen that Dondub Gyatso was a well-educated and high-ranking lama and also, as Buddhist historian Tugan Qutuqtu has suggested, a pioneer in spreading Buddhism among the Volga Kalmyks. ${ }^{8}$ But he returned suddenly to Central Asia

1. "jiyanggiyün / basai se, mergen corji de getukeleme fonjifi / turgüt i ayuki han i k’omang lama $i$ / mugün $i$ taijisa $i$ dorgi jasak $i$ taiji / aisilara taiji sindaci acara, niyalma ojoro, / kadalame muterengge be tuwame sonjofi wesimbufi, / jasak i taiji aisilara taiji sindakini." NCA Mongolia, M1D1-2492.1

2. Tugan Luwsanchoijinyam, Boloryn toli (Ulaanbaatar: Admon, 2006).

3. Gonchok Jigmed Wangbo, Povestvovanie o žizni Vsevedushego Žamyan-Šadby "Brod vedušij k udivitel’no blagomu udelu," trans. with commentary by Nikolai Tsyrempilov (Ulan-Ude: Izdatel'stvo BNC, 2008).

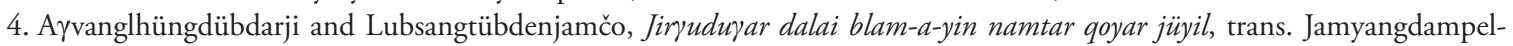

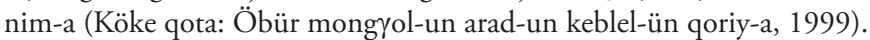

5. Lubsang Pungtsog, the grandson of Dzungar leader Erdeni Bayatur Qungtayiji, also studied there and worked there as abbot of Gomang datsan. Therefore he was also known as Gomang Lama and headed Dzungar monasteries during Galdan Tsering's reign. Junko Miyawaki, "Examples of the Archival Materials on Mongol History Existing outside of Mongolia," in Researching Archival Documents on Mongolian History: Observations on the Present and Plans for the Future (Tokyo: Tokyo University of Foreign Studies, 2004), 195.

6. Gonchok Jigmed Wangbo, Povestvovanie o žizni, 102.

7. Ge. Lijei, Oyirad-un teüke šasin-u sudulul (Ürümči: Sinjiyang-un arad-un keblel-ün qoriy-a, 2002), 193; Terbish Lkhasrangiin, Oiradyn burkhny shashny tovch tuukh, Bibliotheca Oiratica XI (Ulaanbaatar: Soyombo, 2008), 87.

8. Tugan Luwsanchoijinyam, Boloryn toil, 234. The Kalmyk historian Emči Gaban-Shirab, in his chronicle The History of Four Oyirads, mentions Gomang Lama as his main source for the history of the Kukunor Qošuds, in particular the stories 


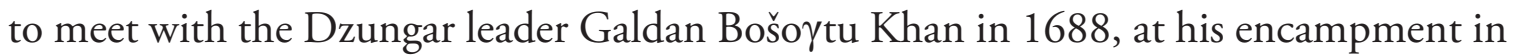
Kobdo. ${ }^{9}$ This meeting was supposedly related to the migration of three thousand Dzungar households to the Ural-Volga region in 1687, under the leadership of Tsagan Batur, the son of Chökür Ubashi. This migration led, in turn, to conflicts between Ayuki and Galdan Bošoytu Khan. ${ }^{10}$ I would suggest that as a high-ranking Torgud lama, he was sent to Galdan Bošoytu Khan by Ayuki to negotiate between the two Oyirad powers on this problem. But from the sources reviewed below, the negotiations ended inconclusively. After the death of Galdan Bošoytu Khan in 1697 one of his commanders, Danjila, headed to Dzungar territory to claim his khan's remains, but near Boyda Eren Qabirya he was suddenly stopped by Gomang Lama’s troops.

Danjila's envoy said to him:

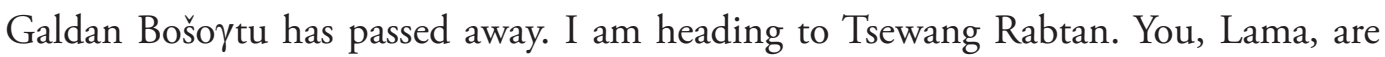

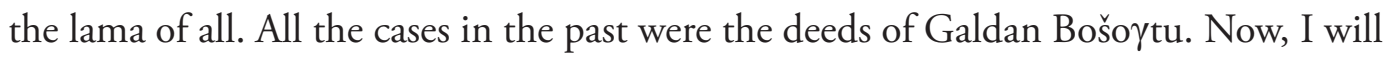
send my envoy to Tsewang Rabtan. And you, Lama, also send with my envoy one good person [to him]. ${ }^{11}$

Gomang Lama withdrew his troops and sent his representative Darqan Gelung to Tsewang Rabtan with Danjila's envoy. But the Qing emissaries were able to persuade Danjila to submit to Kangxi while he was waiting for the return of his envoys to Tsewang Rabtan. ${ }^{12}$ Then Tsewang Rabtan sent one thousand troops under Tsering Dondub, and they captured most of Danjila's men. Danjila and his son, Dorji Sebten, ultimately reached Hami with just seventy-nine men. ${ }^{13}$ One might suspect from this that Gomang Lama and Tsewang Rabtan were allies; later events reveal that they were not. From this time on Gomang Lama would occasionally communicate with the Qing.

about Dalai Qungtayiji. Sükhbaatar Na, Oirad mongolyn tüükhend kholbogdokh survalj bichgüüd III (Ulaanbaatar: Soyombo, 2002), 129.

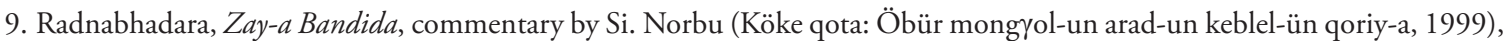
240.

10. On the migration of the Dzungar Tsagan Batur Taiji and the ensuing conflict between Dzungar and Torgud leaders, see Tepkeev V. T., "XVII zuuny süüleer Orosyn ömnöd khesegt Züüngaryn ööldüüd irj nutaglasan ni," Historia Mongolarum 13, no. 397.34 (2014): 16-18.

11. "Yaldan bošogtu ügei bolba. minu bey-e čevengrabdan-i erijü ečimüi. blam-a či bügüde-yin qoyorundu-yin blam-a bolai.

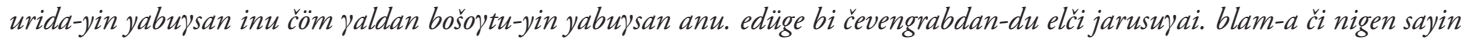

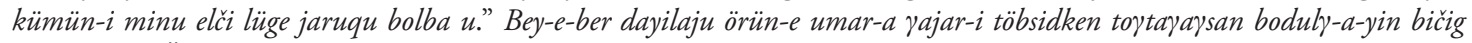
(Köke qota: Öbür mongyol-un soyol-un keblel-ün qoriy-a, 1992), 779-80.

12. Veronika Veit has mistakenly identified him with the Dzungar Gomang Lama, who was a cousin of Galdan Bošoytu Khan. "Galdan's Nephew Danjila (d. 1708): An Example of the K'ang-hsi Emperor's Successful Policy towards the Mongols," Asian and African Studies 16 (1982): 348.

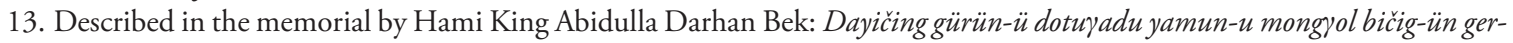

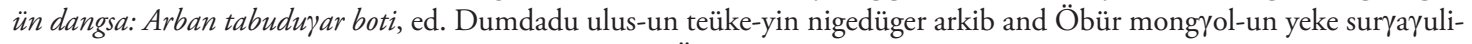

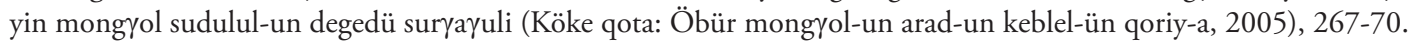


Gomang Lama's letter written in Todo script, dated Kangxi (KX) 37/8/21 (Sept. 24, 1698), was received in Beijing at the beginning of KX 38 (1699) with presents—Russian textiles - together with a letter from Tsewang Rabtan. In his letter, Gomang Lama writes:

I am frightened now that you have blamed me without reason for giving horses to Bošo $\gamma t u$ Khan to use in war against you. You have also accused me of attacking Danjila

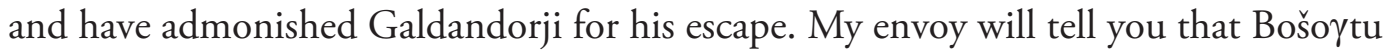
Khan heeded none of my words regarding both Dharma and State in the earth-dragon year [1688]. All of the [Oyirad] noblemen and officials who now serve you, including Danjila and Damba Haška, witnessed it personally. Regarding the events related to Danjila, my envoy will report to you in detail. Danjila himself witnessed it. Regarding the case of Galdandorji, my envoy will also report orally in detail. Rabjamba Namxaibal witnessed it personally. ${ }^{14}$

The Qing emperor had blamed the Torgud lama on three points, but Dondub Gyatso did not recognize the first and only partially accepted the other two. The details of Danjila's adventure can be seen in the above sources. But what does it mean that he "admonished Galdandorji for his escape"?

Galdandorji was the eldest grandson of the Qošud Wčirtu Cecen Khan, who was defeated by Galdan Bošoytu in 1677 and submitted to the Qing in 1679. ${ }^{15}$ In 1697 he escaped from the Bulungir and Qing troops under Ananda. But some of his own subjects and some of the Qoyids of Lubsang did not follow him and were settled by the Qing administration in Alashan. ${ }^{16}$ Kangxi accepted Tsewang Rabtan's submission but ordered that if Galdandorji wanted to return and offered an apology, he should not be stopped. Tsewang Rabtan's envoy Yondan Gelung then reported orally in Beijing at the beginning of Kangxi 37:

Tsewang Rabtan has ordered me to report orally as follows: "Galdandorji did not come to me after his escape but remained with Gomang Lama. When I went to war with

14. Letter from Gomang Lama: "danjilai gi / ideqsen dka ldan rdorje yarči ireqsen xoyorayin učir-tu orotoi muutayal / bošiqtu xa:n-du aqta ögči dayiluulanai geji oro ügei muutayal boloqsan-du / ayiji gi bolji yeke zoboji bainai bi. bošiqtu xan-du šoroi klu

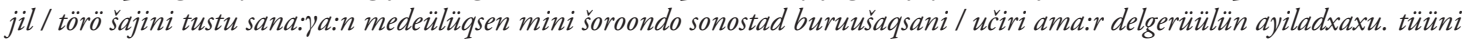
tustu danjila damba xašixa ekilen / tendeki noyod sayid dayar gereči. danjilayin učir de(l)gerü̈̈lji ayiladxaxu. / gerečini mön

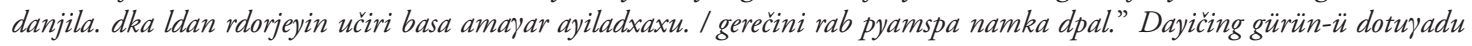
yamun-u mongyol bičig-ün ger-ün dangsa, 354-57.

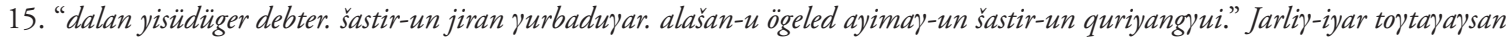

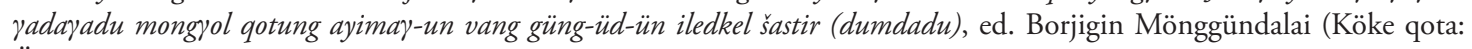
Öbür mongyol-un arad-un keblel-ün qoriy-a, 2006), 537-42.

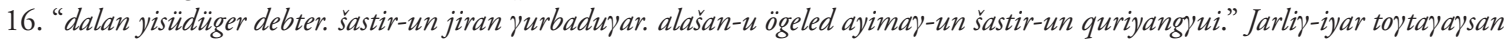
radaradu mongrol, 540-41. 
the Kazakhs, he had promised to join us, but when I reached the Ili River, he ran away from Eren Qabirya to the Moslem city of Kucha and was killed there by the Qoyids. His subjects dispersed to the four ends of the earth. Only his mother and a few of his jayisangs went to the Western side [i.e., Tibet]." ${ }^{17}$

Galdandorji did not submit to Tsewang Rabtan but sought Gomang Lama's support. From this, one can surmise that Dondub Gyatso was powerful enough to be independent of Tsewang Rabtan. Following Galdandorji's death, the relationship between the Qing court and Gomang Lama was again normalized. Envoys from Gomang Lama visited Beijing in 1699, 1700, and 1702 and inquired after the emperor's health. In 1701 there was no mission from Gomang Lama because he had gone to Tibet. Gomang Lama's messenger, who arrived in Beijing in 1702, asked the officials of the Lifanyuan for a protection document, as he had been robbed on the way from Tibet to Beijing. ${ }^{18}$ Gomang Lama went to Tibet, both for pilgrimage and also under strong pressure from Tsewang Rabtan, who had begun pursuing a policy of Oyirad unification, as had his predecessor Galdan Bošo $\gamma$ tu Khan. Arriving in Lhasa, Dondub Gyatso met his disciple Jamyang Shadba I--an abbot of Gomang datsan, as Dondub Gyatso had once been. Gomang Lama made generous donations to the disciples of Gomang datsan and, at the request of Jamyang Shadba, received an allotment of land for the construction of a hostel for lamas and disciples, thereby making great donations to the Dalai Lama's treasury. ${ }^{19}$ Soon after this, the Dalai Lama's administration appointed Gomang Lama abbot of Litang monastery, in eastern Tibet in Kham. But he then came into conflict with Gombo Tsering — 'warlord' of the Changtui region on the Tibetan-Chinese frontier ${ }^{20}$ who attacked him. Gombo Tsering, who shortly before this conflict had submitted to the Qing, complained to the Qing administration in Dajianlu in Sichuan and asked for help. ${ }^{21}$ Envoys of Gomang Lama came to Dajianlu bearing a letter from their master:

This place named Changtui has been ruled by Litang since ancient times. We have records of their tax collection and military service. Local inhabitants used their adverse terrain to freely rob merchants and travelers .... When I came here from Central Tibet, about thirty robbers from Changtui killed my people-Rinčin Jayisang and

17. "zewang rabtan mimbe anggai wesimbu / sehengge, g'aldan dorji ukame jihe manggi, mini jakade jihekū. g'omang lamai jakade tefi / bihe. amala bi hasak be coohalambi sere jakade, i inu cooha de genembi seme / holtome gisurefi, bi ili sere bira de isinaha manggi, i geli eren habirga ci / ukafi hoise i tehe küca hoton de genefi hoit $i$ urse de wabuha. ini / fejergi urse gemu duin ici samsihün, g'aldan dorji i eniye emu udu jaisang / sebe gaifi wargi baru genehe seme wesimbu." Dayičing gürün-ü dotuүadu yamun-u mongyol bičig-ün ger-ün dangsa, 505-8.

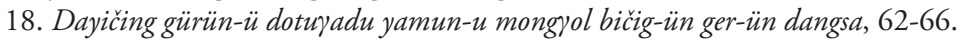

19. Gonchok Jigmed Wangbo, Povestvovanie o žizni, 166-67.

20. The region Nyag rong (in Tibetan, or Xinlong in Chinese) in modern-day Garze Tibetan autonomous prefecture of Sichuan province, PRC, sits directly to the north of Litang in the same prefecture. On the history of this area, see Xiuyu Wang, China's Last Imperial Frontier: Late Qing Expansion in Sichuan's Tibetan Borderlands (Lanham, Md.: Lexington, 2011$), 72$.

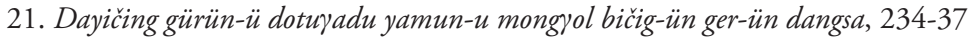


Erke Bayatur — and stole their horses, saddles, rifles, and clothing. . . . Resenting their evil behavior, I have sent my troops to peacefully bring them here. My troops took their two forts, which offered resistance. Another four or five forts capitulated. . . Now, at your request, my troops have withdrawn. ${ }^{22}$

This letter was received in Beijing on KX 42/8/30 (Oct. 10, 1703). The further course of events there are unknown to me. But from the biography of the sixth Dalai Lama, one learns that Gomang Lama Dondub Gyatso was still on the abbot's throne in the Litang monastery in $1708 .^{23}$

Working with Manchu-language microfilm held by the First Historical Archives in Beijing, I have found new evidence regarding Gomang Lama. One document, from which only the imperial rescript portion survives, reads:

Because of Gomang Lama's rebellious actions, one cannot retain him there for a single day. When this janggin arrives there, send him along with his disciples and servants, totaling not more than ten people, by way of internal post stations. Send the other people with one janggin to his subjects in Dang Serten and wait for further orders. For the others, let it be as originally recommended..$^{24}$

One can see here that the Qing government finally decided to intervene in the conflict between Dondub Gyatso and the Nyag rong ruler. There is another memorial with an imperial rescript in red ink from KX 49 (1710). From this memorial by Bafušeo we find out that

Gomang Lama came into conflict with local people. And he also has bad relations with the inhabitants of Köke nayur (Qinghai). If we send him to Dang Serteng, we cannot be sure that he will not cause problems. Six hundred households in Dang Serteng and

22. Manchu translation of a Tibetan letter from Gomang Lama to the Qing official in Dajianlu Dambaserji: "jan dui serengge daci litang ni harangga ba. yaya alban gaiha coohai hacin, alban de / yabubuha hacin gemu dangse de bi. jan dui urse ini ba na $i$ haksan de hafirahün de erdufi / yaya hüdašara yabure urse be heturefi durime cuwangname günin $i$ cihail yabumbi . . bi zang-ni baci / ebsi jiderede jan dui i güsin funcere hülha jifi mini fejergi rincin jaizang / erke batur juwenofi be miyoocilame wafi morin enggemu miyoocan, etuku i jergi jakan be I durifi gamaha. . . . tesei / ere gese ehe yabun i yabure de bi fancafi mini ubaci cooha unggifi damu / hüwaliyasun i wajikini sehe bihe. mini unggihe cooha de tese iseleme of / juwe gašan be gaiha. ini cisui dahame dosika gašan duin sunja bi . . . suweni tacibuha gisun i songkoi cooha be gocika." Dayičing gürün-ü dotuүadu yamun-u mongyol bičig-ün ger-ün dangsa, 243-50.

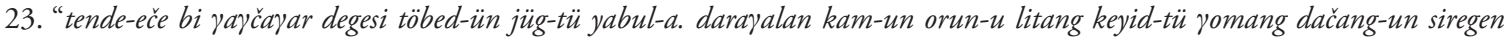

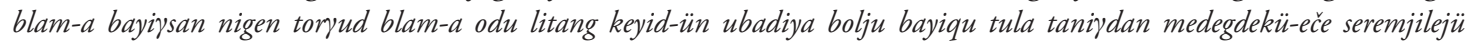

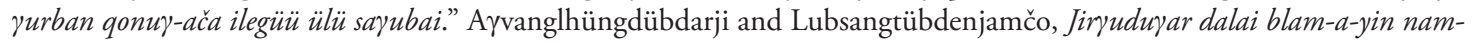
tar qoyar jüyil, 50.

24. "gomang lama emgeri afatame facuhün yabuha be dahame, tubade emu inenggi fulu bibuci ojorakū. ere janggin isinahai ini hanci yabure šabi kutule be juwan niyalma be tulemburakü, dorgi juhün (sic!), giyamun yalubufi gajikini. funcehe niyalma jai emu janggin tucibufi dang serteng de bisire niyalma de acabufi hese be baikini. güwa be gisurehe songkoi obu." Kangxi chao Manwen zhupi zouzhe 康熙朝満文朱批奏折, microfiche 8 . 
one hundred men with Šanjotba have resettled from Litang and must be resettled in Köke qota (Hohhot) with Gomang Lama. Šanjotba and the others who were resettled from Litang have thin clothes, and their cattle are exhausted. Thus Šanjotba and the others cannot be resettled in Köke qota immediately. Let Šanjotba and the others live temporarily in Dang Serteng for one or two years, and then move them immediately [to Köke qota]. Because they will not be moved now to [Köke qota], send one janggin there to supervise them." ${ }^{25}$

While the emperor was away from the capital, Gomang Lama waited for him in the imperial horse pastures north of Zhangjiakou. But on his way to Beijing, on KX 49/5/22 (June 18, 1710), Gomang Lama passed away near Anguli nayur in modernday Hebei province. ${ }^{26}$ As was customary in the hot season, his disciples cremated his body after receiving permission. ${ }^{27}$ The Qing official Bafušeo, who escorted them, memorialized the emperor and recommended sending his senior disciple Erke Ončon to the capital in place of the deceased Gomang Lama. Erke Ončon would then return when the subjects of Gomang Lama arrived in Köke qota from the pasturelands of Dang Serteng. ${ }^{28}$ I regret that I cannot trace the development of these events further.

Even from the sketchy sources available, one can see that Gomang Lama Dondub Gyatso was not just a religious figure but also a politician who played an active role on the Inner Asian political scene between Oyirad polities like the Kalmyk khanate, the Dzungar state, Tibet, and the Qing Empire at the end of seventeenth and beginning of the eighteenth centuries. His attack on Danjila and Galdandorji's decision to flee toward him both clearly show the power and potential of Gomang Lama. But in the face of Tsewang Rabtan's policy of unification, he had to move into Tibet, where the Dalai Lama's government decided to use Gomang Lama's power along the unstable frontier zone of Nyag rong in southeastern Tibet. However, Dondub Gyatso came into armed conflict with the Nyag rong ruler Tsering Gombo and, as a result of that, was forced to

25. "g'omang lama bai niyalmai emgi eherefi ishunde afanduha huhu noor $i$ urse i emgi geli acuhün akü. dang serteng de unggici baita dekdebure be boljoci ojorakū. uttu be dahame dang serteng de bisire ninggun tanggü boigon i niyalma, litang ni baci guribume gajiha šanjotba i jergi tanggü isire niyalma be sasa guribufi, g'omang lama i beye be suwaliyame huhu hoton de tebuki. litang ni baci guribume gajiha šanjotba se eturengge nekeliyen, ulha macufi šadaha be dahame, šanjotba sebe ergemburakü, uthai huhu hoton de guribuci ojorakū. šanjotba sebe taka dang serteng ni šurdeme emu juwe aniya ergembume tebufi jai guribuki, ne esebe taka guriburakü be dahame janggin emke unggifi tuwašatame tebuki." Kangxi chao Manwen zhupi zouzhe, microfiche 8 .

26. "g'omang lama be gajime sunja biyai juwan ninggun de angguli bade isinjifi g'omang lama yabufi ojorakū of indeme ineku biyai orin juwe i indahün erinde akù oho." Kangxi chao Manwen zhupi zouzhe, microfiche 8.

27. Ibid.

28. "g'omang lama be sunjai biyai orin juwe de akū oho, ini giran be ini šabisa de afabufi, jafabuha be dahame, erebe aisilakü hafan bafušeo de bithe unggifi g'omang lama i giran be jasei tule emu bade taka sindakini. ini ne dahame genehe šabi erke oncong sebe ging hecen de gajifi, kemuni da tehe cung guwe ze de tebuki. ceni dang serteng de bisire urse be hubu hoton de guribufi isinjiha erinde, erke oncong sebe huhu hoton de unggifi ceni hoki de acabufi tebuki." Kangxi chao Manwen zhupi zouzhe, microfiche 8. 
submit to the Qing. Here one question arises: why were the šabi-subjects of Gomang Lama not moved to Köke qota but resettled in western Qalqa instead? This question is the central concern of the next section.

\section{2. Šabi subjects of Gomang Lama, headed by Mergen Tsorji}

In the Yongzheng emperor's edict to the Kalmyk khan Tserin Donduk in 1729, he mentioned the $\check{s} a b i$ subjects of Gomang Lama as follows:

When your Arabjur, son of Nazar Mamud, tried to return after the pilgrimage with his mother to Tibet, Tsewang Rabtan did not permit him to pass through, and he could not go back. I then mercifully granted him the title of beise and much grace and gave him pastureland of his own. Also, the disciples of Gomang Lama were captured by Tibetans and could not return [to you]. I gathered them all and granted my favor. ${ }^{29}$

But from this letter one cannot determine the exact date of the events mentioned or how Gomang Lama's people arrived in western Qalqa. At the beginning of this paper, I mentioned the Manchu language documents from the National Central Archives in Mongolia. In one, which has lost its beginning and end, Mergen Tsorji, the ruler of this group, said:

Among us there are three tayijis who are relatives of Ayuki Khan and twelve tayijis who are relatives of our Gomang Lama. ... We are all from the Kalmyk ${ }^{30}$ state. . . In the past our Ayuki Khan advised us by letter, "The people who left with [Gomang] Lama, the lamas, and others are all my subjects. Because Amuhūlang khan rules over the Celestial Empire, you do not have to worry. You can live where you want and submit to whom you want." We have sent this letter for presentation to Emperor Shengzu [the Kangxi emperor]. And we have received an imperial rescript, under which we were living freely. ${ }^{31}$

29. "tan-u najar mamud-un köbegün arabjur öber-ün eke lüge qamtu baraүun töbed-tür mörgür-e irejü qariju odqui-dur,

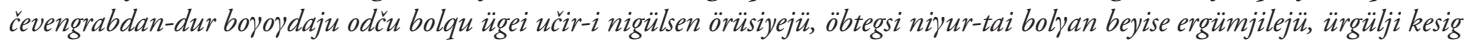

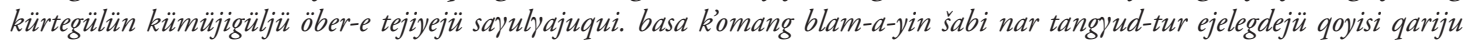
bolqu ügei-yin tulada, čöm quriyajad kesig kürtegülün tejiyebei.” Altanorgil Badai and Erdeni, Oyirad teüke-yin durasqal-ud (Ürümči: Sinjiyang-un arad-un keblel-ün qoriy-a, 1992), 457-59.

30. I've translated Turgūt here as Kalmyk, since it included more than only Torguds.

31. "damu meni dorgi ayuki han i mugün i / taiji ilan, meni k’omang lama i mugūn i / taijisa juwan juwe . . be gemu turgüt gurun i niyalma. . . . damu neneme meni ayuki han i / mende unggihe bithede, lama i / emgi genehe lama albatu gemu / mini harangga / amuhülang han, abkai fejergi baita / icihiyara be dahame suwembe jobobure / ba akū. we ya de ome / alibure suweni cihanggai bade / banjime tekini sehe bithe be / šengzu ejen de tuwabume / wesimbufi, baiha songkoi šangnaha / ejehe bithe be 
It seems that, although Gomang Lama Dondub Gyatso was not a close relative of Ayuki Khan, he was still a representative of the Torgud ruling lineage. And for this reason he could receive Ayuki Khan's permission to rule that part of his subjects who went with him to the east. This letter from Ayuki Khan was probably presented to the Kangxi emperor after the death of Gomang Lama in 1710.

Before going further, I must identify the above-mentioned Mergen Tsorji, who ruled the subjects of Gomang Lama after his death. On KX 46/10/20 (Nov. 13, 1707) the Qing Lifanyuan received the letter of a certain Noyon Corji, son of the older brother of the Torgud Gomang Lama, written in Todo script, asking after the emperor's health. ${ }^{32}$ I suspect that this man was Mergen Tsorji. Since Dondub Gyatso was from the Torgud noble family, his nephew could be titled Noyon Corji (lit., noble abbot). The location of this group under the rule of Mergen Tsorji/Noyon Corji is known from the Qing official chronicle of the conquest of the Dzungar state. On the red tiger day of KX 54/11 (1715) the Qing official Funingga begged the emperor's permission to send scouts to the region of Gas. His memorial read:

Funingga memorializes again. Serteng, where the beise Arabjur and Noyan Corji resided, and Caidam, where the subject-tayijis of Dayan Taiji resided, are connected to the road between Cagan Cilootu and the pass of Gas. ${ }^{33}$

The letter from General Basai to Vice-General Danjindorji, dated YZ 6/3/7 (April $15,1728)$, cited another letter from Mergen Tsorji, from which one can determine when the Torguds had left the above-mentioned pasture:

The letter presented from Mergen Tsorji, which he begs to transmit, said: "When we moved out from Dang Bulunggir the people of forty-nine households escaped. After finding out that thirteen men from that group are now subject to Duke Baji, seven to Duke Tongmok, and twenty-two to Duke Tuba, we have written to the Lifanyuan and received back our thirty-three men. The Lifanyuan ordered Duke Tuba to hand over to me the nine men who were not obtained. When I asked Duke Tuba to give me [those nine] men, Duke Tuba said: 'When I reported to the Lifanyuan, those nine men were under me. Then I divided them with Duke Tongmok, and now they are under him. You have to request them from Duke Tongmok!' When I requested them from Duke

dahame, sula jirgame / tehe bihe." NCA Mongolia, M1D1-2492.6.

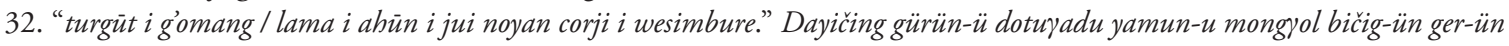
dangsa, 369-71.

33. "funingga i dahüme wesimburengge. beise arabjur. jai noyan corji sei tehe serteng ni jergi ba, dayan taiji i harangga taijisai tehe caidam i jergi ba. gemu gas angga i cagan cilootu jugūn de hafunambi.” Fuheng 傅恆 et al., comp., Jun gar i ba be necihiyeme toktobuha bodogon i bithei julergi banjibun. Ilaci debtelin (NCA). 
Tongmok, he said: 'I already returned your seven men. These nine men were given to me by General Arna. They cannot be handed over to you.' Now, in the sixth month, our men recognized another six men besides those nine in the banner of Duke Tongmok. Six men were found in the banner of Duke Baji, other than those thirteen who were returned to us earlier. When I asked them to return those people, they replied that 'you must report to the Lifanyuan to get them. Without the permission of the Lifanyuan, they cannot be returned.'"34

The Dang and Bulunggir mentioned here are rivers in the northwestern Köke nayur region. River Dang empties into Lake Serteng. Obviously, the Torguds of Mergen Tsorji moved into western Qalqa from this region. Mergen Tsorji requested the return of his subjects who had fled during this migration and had been kept in several banners of western Qalqa. One of the banner rulers, Duke Tongmok, did not return his Torguds, reasoning that they were given to him by the Qing General Arna.

From the official biography of Tongmok one finds that in YZ 2 (1724), he joined the expeditionary forces of General Arna, which were to block the withdrawal of Lubsangdanjin's rebel army. ${ }^{35}$ General Arna, stationed at Turfan, died at the end of that same year. Thus it seems that those nine men were given by Arna to Tongmok in 1724, at the same time that the Torguds moved out from that region to Qalqa.

The reason for that migration was presumably as follows. In YZ 1/7 (1723), before the arrival of the Turfan general and on account of Lubsangdanjin's uprising, General Nian Gengyao recommended that the emperor build a fortress in Bulunggir and garrison an army there. The emperor granted permission for this. ${ }^{36}$ By imperial edict the Mongols were prohibited from nomadizing in this region. ${ }^{37}$ So this group under Mer-

34. Letter of General Gung Basai to Qalqa’s vice-general Prince Danjindorji: “lama mergen corji i alibuha / bithede, ulame yabubure be baire jalin / be dang bulunggir ci gurime jidere de, / ukaka dehi uyun boigon i dorgi gung / baji de juwan ilan anggala niyalma, / gung tongmok de nadan anggala niyalma, gung / tuba de orin juwe anggala niyalma bi / seme, harangga jurgan de bithe alibufi / uheri amba ajige güsin ilan anggala be I amasi gajihaci tulgiyen, bahara, unde uyun / anggala be minde bukini seme jurgan ci / gung toba de bithe isinjiha bihe. gung / tuba de niyalma gaji sehede, tuba i / gisun, jurgan de boolaha fonde, uyun / anggala niyalma minde bihe. gung tongmok / mini emgi niyalma dendere de, gung tongmok de / buhe. suwe gung tongmok ci gaire dabala / sembi. gung tongmok ci niyalma bošoci, tongmok i / gisun, suweni nadan anggala niyalma be buhe I kai, ere uyun anggala niyalma, jiyanggiyūn / arna minde buhengge, suwende buci ojorakü / sembi. ne tongmok de bisire uyun anggala ci / tulgiyen, geli baicaci, meni niyalma ere / aniyai ninggun biyade gung tongmok i güsa de, / geli ninggun anggala niyalma takaha, gung / baji ci neneme gaiha juwan ilan niyalma ci / tulgiyen, geli meni ninggun anggala niyalma be / takaha, deseci gaji sehede desei gisun, / suwe jurgan de boolafi, jai gaici / ojoro dabala, jurgan i bithe akü oci, buci ojorakü sembi." NCA Mongolia, M1D1-2492.1

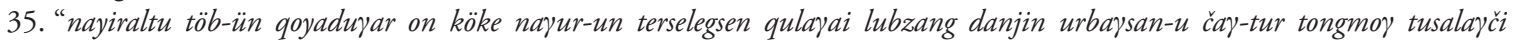

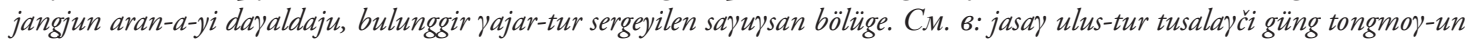

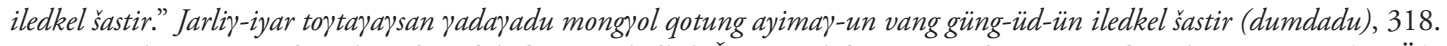

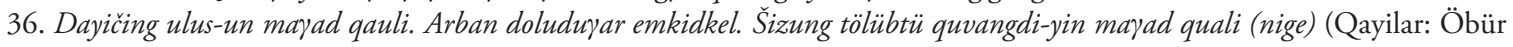
mongyol-un soyol-un keblel-ün qoriy-a, 1992), 381.

37. Shuhui Wu, Die Eroberung von Qinghai unter Berücksichtigung von Tibet und Khams 1717-1727: Anhand der Throneingaben des Grossfeldherrn Nian Gengyao (Wiesbaden: Harrasowitz, 1995), 277. 
gen Tsorji moved to western Qalqa. Duke Tongmok and Duke Tuba from western Qalqa, who had nomadized together with the Qošuds in the Köke nayur region after the Dzungar invasion of Qalqa at the end of the seventeenth century, served in the army of General Arna. Additionally, the banners formed from the Oyirads who had submitted to the Qing Empire had been organized in western Qalqa by that time.

\section{The establishment of the Torgud jasay banner- 1728}

The Torguds of Mergen Tsorji had arrived in western Qalqa in 1724. According to the Kangxi emperor's rescript, they could not live "freely" in this new place, as they had in their previous location; rather, they were to be organized into the Qing administrative system. Regarding this situation, the undated document cited above says:

[Our] people thought: "Qalqa and Oyirads were all separately organized into banners and nirus, with their nobles at the head. No one was given to other people. We are all people of the Kalmyk state. It is true that we do not want to be included in any Qalqa or Oyirad jasay's banner. How could we lie to the Emperor fearlessly? Likewise, we will be organized separately." Now how could I, Mergen Tsorji, dare to disobey the Lifanyuan's order, even though the mind of [our] people is different? The banner of the Oyirad jasay beise Dorjisebten lies next to us. So let us be included in the banner of Beise Dorjisebten. ${ }^{38}$

The Lifanyuan's order is also cited in this document: "The letter of the Lifanyuan [says], 'You are a monk. It is difficult for you to rule so many people. You should be organized administratively and included in the one of the neighboring banners."'39

Obviously, the Torguds did not want to obey anyone from the beginning. But since their leader Mergen Tsorji was a clergyman, the Qing administration ordered them to obey one of the neighboring jasays. So Mergen Tsorji's choice of Dorjisebten's banner was motivated by the earlier relationship between Gomang Lama Dondub Gyatso and Danjila, the father of Dorjisebten. But Mergen Tsorji's subjects were not willing to obey anyone, reasoning that they were people of the Kalmyk khanate. The Qing administration in Qalqa also took this situation into account. In a secret memorial by the

38. "geren i günin, kalka, I ület sebe güsa, niru banjibufi / meni meni wang taiji sebe jasak / obufi, ceni harangga urse be kamcibuhabi. umai encu niyalma de / kamcibuha ba akù. be gemu turgüt gurun i niyalma. kalka, ület i / jasak sede cihanggai kamciki sere / günin yargiyan i akü bime. ai / gelhun akü cihangga seme enduringge ejen be holtombi. ainci membe / encutebumbi tere

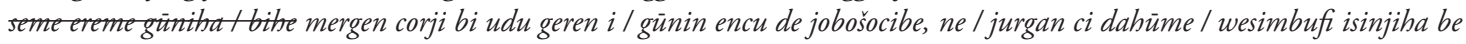
dahame, ai / gelhun akü jurcembi. ület i / jasak beise dorjisebten meni / hanci tehe be dahame, beise / dorjisebten de kamcifi teki seme / alibuhabi." NCA Mongolia, M1D1-2492.6.

39. NCA Mongolia, M1D1-2492.6. 
vice-general, imperial-son-in-law Tsering, dated YZ 5/12/25 (1727), he reports to the emperor on the current situation:

Your servant previously spoke with Prince Danjindorji, General Basai, and ViceGeneral Bubei on the following topic: "Mergen Tsorji has refused to be organized into a banner, even though the generals had instructed him on the necessity of it. They are not willing to be put in the banner." Your servant does not know whether Mergen Tsorji really wants to move here. Currently he and his men live in western Qalqa. [We] need to resolve this problem in a different way. I am somewhat worried about this. Western Qalqa is very close to Tsewang Rabtan's territory. Also Princes Tsering Wangbu and Sebten Wangbu are themselves in the inland area [China], and their subjects dwell in the region of the River Tui. They go continually into Tuvan territory to collect tribute from the Tuvans and to trade with them. And at the same time they feed Tsewang Rabtan with information. [We] should not trust these Oyirads. Their older generation is already dead, and they now have just the younger generation. Let us move them into Köke qota near to their princes and move the disciples of Mergen Tsorji into the land thereby opened up. Informing Tsering Wangbu and Sebten Wangbu about it will let us send a small number of households to Tuva to collect that tribute and to live with the Tuvans. Let them send the collected tribute to Köke qota at the end of each year. This kind of decision will not burden their lives and can preclude any problems. For this reason, I, your servant, secretly memorialize you. I respectfully request your imperial edict. $^{40}$

The emperor ordered the Lifanyuan to explore this issue in detail and recommend a decision. At the same time the administration of General Basai started to organize the subjects of Mergen Tsorji into the banner system.

Our administration has again asked Mergen Tsorji. He said that they are willing to be included in the banner of the Oyirad Dorjisebten. So we have appointed the banner commander, military commander, arrow commanders, and other officials of the banner, putting 150 men in each arrow. What should we do with the remaining fiftyfive men: give them as the servants to those princes who will be ranked by law or who have own subjects, or organize from them into half-arrows? We will follow the order after receiving it from the Lifanyuan. ${ }^{41}$

40. Zhongguo diyi lishi dang'anguan 中国第一历史档案馆et al., eds., Yongzheng chao Manwen zhupi quanyi 雍正朝满文 朱批全译 (Beijing: Huangshan shushe, 1998), no. 2807, pp. 1552-53. I am deeply grateful to professor O. Oyunjargal (National University of Mongolia) for translating this passage from Chinese into Mongolian.

41. Letter from General Basai to the vice-general Prince Danjindorji, YZ 6/3/7: "meni baci lama mergen corji de, dasame / fonjifi cihangga ület $i$ beise dorjisebten de / kamciki seme güsa be kadalara janggin, / meiren i janggin, nirui janggin i jergi hafasa I sindafi emu tanggü susai haha be emu niru / obuhaci tulgiyen, funcehe susai sunja haha / eici taijisa de jergi bahabufi kamcigan 
General Basai organized three nirus from the Torguds of Mergen Tsorji (the document earlier states that Mergen Tsorji had about five hundred households). ${ }^{42}$ One can see that the total number of people under Gomang Lama decreased from six hundred households in 1710 to five hundred in 1728, obviously caused by migration. Much was written about the search for escapees who fled along the way to western Qalqa. Some escapees were found in the banners of the Qalqa Princes Tongmok, Tuba, and Cedenjab, and among the banner of Qoyid Prince Baji. ${ }^{43}$

Shortly after this General Basai submitted another memorial, in which he requested the organization of a banner for Mergen Tsorji's Torguds under a separate jasa .

General Basai's memorial stated:

"On the organization of a separate jasay banner for the Torguds under Mergen Tsorji. Prince Lama Rabjamba Keirub, a relative of Ayuki Khan, is a trustworthy man. He said that he is willing to leave his post as lama to serve as jasay of the banner. Princes Erke and Dural are relatives of Gomang Lama. Both are good enough for service. All of their people agree with this. So let us appoint Ramjamba Keirub as the jasay prince and Erke and Dural as the assistant princes of the banner. Mergen Tsorji will still be the man in charge. Let them consult with him on questions [of the banner]."

On YZ 6/3/12 (April 20, 1728), a memorial submitted by Yenjana, imperial bodyguard of the second rank of the Jian Qingmen Gate, ${ }^{44}$ included the suggestion of General Basai, "to appoint Keirub as jasay prince and Erke and Dural as assistant princes of the banner. Let the ministry order the casting of a seal for the banner's jasay and distribute it." On the same day the Grand Council's officials received the imperial edict with the rescript- "Let it be as recommended." 45

I bahabure, jušen bisire taijisa de kamcigan / bahabure, eici hondoho niru banjibure babe, / jurgan ci toktobufi unggihe erinde dahame / yabuki sehebi." NCA Mongolia, M1D1-2492.1.

42. Op. cit.

43. Letter from General Basai to the vice-general Prince Danjindorji, YZ 6/3/7: "baicaci, / neneme lama mergen corji dang / bulunggir ci gurime jidere de / ukaka dehi uyun boigon i dorgi, I takaha gung baji de juwan ilan / anggala, gung tongmok de nadan / anggala, gung tuba de orin / juwe anggala niyalma be bahabureo / seme alibuha be, meni jurgan ci / gung tongmok, gung tuba, baji de / lama mergen corji i niyalma be / amasi bu seme yabubuha be / dangsede ejehebi. te lama mergen / corji neneme takaha tongmok i / güsade uyun anggala, geli / takaha ninggun anggala, baji i / güsade geli takaha ninggun / anggala, beile cebden i güsade / takaha emu haha. ere jergi / urse güsa, niru de dosimbuci / acarangge sehebe dahame, erebe / gung tongmok, baji, beile cebden de I ton i songkoi lama mergen corji de bahabukini. aika encu turgun bici, turgun be / tucibume boolanjikini seme bithe unggiheci / tulgiyen, ere jergi urse be, güsa, / niru de dosimbure be sakini seme, juwe / biyai orin nadan de isinjihabi. uttu I of, lama mergen corji de yabubuhangge, I ere baitai jalin, beile cedenjab, gung baji, I gung tongmok sede ere jergi niyalma be / jurgan i bithe be dahame ton i songkoi, / lama mergen corji de afabume benebu / seme yabubuhaci tulgiyen, ere bithe / isinahai, sini baci niyalma tucibufi / hüdun bargiyame gaisu. ere orin juwe / anggala niyalma be gemu güsa, niru de / dosimbure be dahame esei dorgide, uksin i / hahai ton de dosimbuci acara niyalmai / gebu, ton be hüdun benju. niru banjiburede / aliyahabi. goidabuci ojorakü." NCA Mongolia, M1D1-2492.1.

44. The Yenjana mentioned here was a member of the famous Tulišen mission to Russia in 1712-1715 and had visited the residence of Kalmyk Khan Ayuki.

45. Letter from General Basai to the vice-general Prince Danjindorji, YZ 6/3/28: "jiyanggiyun basai sei / wesimbuhe bithe be 
From this document one can see that the Yongzheng emperor established a separate Torgud banner headed by a certain Keirub, a former Buddhist monk and a relative of the Kalmyk Khan Ayuki. Perhaps Gomang Lama's family line was not close enough to Ayuki Khan for him to be considered a close relative of latter. But as shown below, real power was still in the hands of Mergen Tsorji, appointed by imperial edict to be the leading figure of the newly established banner.

The question of how to organize the remaining fifty-five men who had not been included in the nirus still lingered. The vice-general, Prince Danjindorji, refused to meet Basai immediately to deliberate about the matter, reasoning that the Torguds could wait a little longer. ${ }^{46}$ Unfortunately, I cannot find any document on the resolution of this question. From the extant letters of General Basai, one finds that Mergen Tsorji went to Beijing for an audience with the emperor and that the general asked him to personally memorialize on the remaining questions of the banner to the Lifanyuan. ${ }^{47}$

In another fond of the Mongolian National Central Archives, that of the Manchu governor-general of Uliyasutai, I have found one more document where the Torgud banner of Mergen Tsorji was mentioned. The document is entitled "Book of all purchased cattle: important records of payments and receipts." Due to war with the Dzungars, the jasays of the Mongol banners were forced to sell horses and camels to the Qing troops stationed in Qalqa. On page 17 of the record book is the following note:

On [YZ 6/7]/20 (Aug. 25, 1728) 2,140 taels of silver were handed over to Prince Sambil Erke from the banner of the vice-general and the banner commander and to Bandi from the banner of the Jasa 7 Prince Idamjab for 180 horses, 20 camels, and 400 sheep of the banner of Torgud Lama Mergen Tsorji and Jasay Prince of the First Rank Keirub. $^{48}$

tuwaci, turgüt i / lama mergen corji sebe gūsa, niru / banjibufi, encu jasak oburede, ayuki / han i mugün i taiji lama ramjimba I keirub be, niyalma umesi unenggi, ini / beye cihanggai lama ci nakafi, jasak / ofi, hüsun bume faššame yabuki sembi. / k’omang lama i mugün i taiji erke, dural. I ese gemu haha sain, niyalma ombi. I geren gemu günin dahara be dahame / ramjamba keirub be jasak i taiji sindaki, I erke, dural be aisilara taiji sindaki. I mergen corji te baita icihiyaha niyalma, I ese gemu ice dahaha be dahame, yaya / baita be kemuni mergen corji i emgi / hebešebume icihiyabuki seme /*wesimbuhe be dahame jiyanggiyün basai sei /*wesimbuhe songkoi keirub be jasak taiji / sindaki. erke, dural be aisilara / taiji sindaki. jasak i doron bure / babe harangga jurgan de afabufi, / hungkerefi bukini sembi, seme hüwaliyasun / tob i ningguci aniya ilan biyai juwan / juwe de, /*giyan cing men i jai jergi hiya yenjana / sede bufi ulame wesimbuhede, ineku / inenggi hebei weng, ambasa be / dosimbufi, /*hese wasimbuhangge, gisurehe songkoi obu." NCA Mongolia, M1D1-2492.2.

46. Letter of the vice-general Prince Danjindorji to General Basai, YZ 6 after the ninth month: "jušen akū taijisa de sidan $i$ niyalma bure kooli I akū. Lama taijisa de jergi kamcigan bahabure / toktobuha kooli akū, ere baitai jalin, jurgan ci / afabuha songkoi acafi, whei toktobume gisurefi / icihiyaha babe boolara be dahame, giyan i beye / uthai geneci acambihe. ne benjihe ciyaliyang / wajire unde, yamji cimari geren güsade salame / bume wajire hamika bicibe, jakün biyai ice de / meni aiman i geren güsa orkon tola i belcir i / bade culgan acambi. uttu ofi, ne beye bahafi / generekū. jaka aisilara jiyanggiyūn, wang efu / generede, meni boljohongge, uyun biyai juwan $i$ šurdeme / jiyanggiyūn i coohai hüwaran de isafi gisureci / acara baita hacin be acafi gisureki sehe bihe. I turgüt se, ice dahaha urse be dahame I membe aliyaci oci, aika aliyafi uhei toktobume / gisurefi icihiyaha babe, jurgan de boolaci / ojoroo." NCA Mongolia, M1D1-2506.1.

47. Letter from General Basai to the vice-general Prince Danjindorji, YZ 6/10/17, in NCA Mongolia, M1D1-2492.5.

48. "orin de turgūt i lama mergen corji, jasak i / uju jergi taiji keirub i gūsai emu / tanggū jakūnju morin, orin temen, duin / tanggū 
Fortunately, the letter from Mergen Tsorji and the Jasa $\gamma$ Prince Keirub survives, shedding light on this question:

Letter from the Torgud Mergen Tsorji and the jasay [Keirub], submitted to the general, Prince [Danjindorji]. This is the answer on the matter of selling cattle [to the army] according to the imperial edict. We had suffered greatly on our way to here from afar. And since then little time has passed. Nevertheless, reflecting on the matter raised in the edict, we took 20 camels, 180 horses, and 400 sheep, even from the poor households, although they were not offered to us for sale. The total price for the cattle was 2,140 taels of silver. This letter was submitted with the khadag present on the sixth day of the last month of the summer of the sixth year of the Yongzheng reign. ${ }^{49}$

At the end of this letter is an impress of the square seal inscribed with three lines in Phagspa script, which reads as follows: ↔jo-reg / tu-k'o-šón / če-t'a-'iji. It is hard to

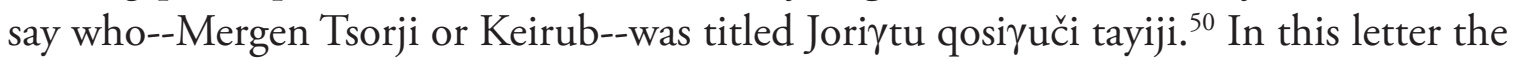
name of Mergen Tsorji is written before the jasay of the banner, whose name is even not mentioned. One can surmise that the real power of the banner was still in the hands of Mergen Tsorji.

O. Oyunjargal has found that the Oyirad league, which consisted of the submitted Oyirad banners, was established in western Qalqa during the same sixth year of Yongzheng (1728). ${ }^{51}$ In Qing sources the total number of banners varies between five and six. Based on the Biographies and Records of the Outer Mongolian and Muslim Princes and Dukes, she found that the Oyirad League consisted of the following banners: 1) Jasa

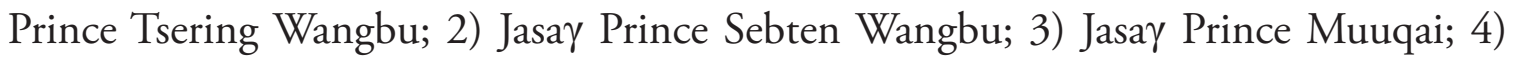

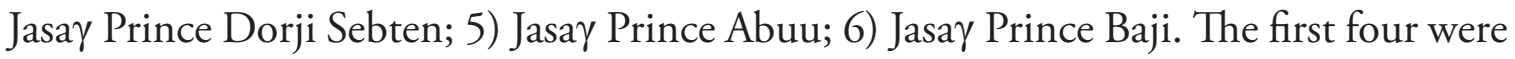
Dzungar nobles, while the fifth and sixth were Qošud and Qoyid, respectively. From their original locations, Abuu had moved to the Köke nayur region, and this is the reason that Oyunjargal offers for the documents sometimes recording varying numbers of banners.

honin i hüdai juwe minggan emu / tanggü dehi yan menggun be, menggun benebume / takürara aisilara jangjun wang ni güsai I taiji sambil erke, jasak i taiji idamjab i / güsai güsa be kadalara janggin bandi de afabume buhe] uheri uncara ulgai dangse menggun buhe, gaire oyonggo dangse." NCA Mongolia, M2D1-3.17.

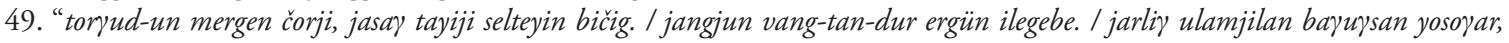

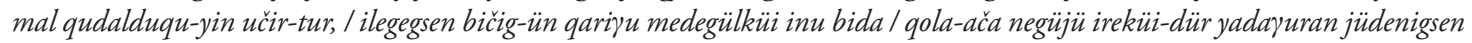

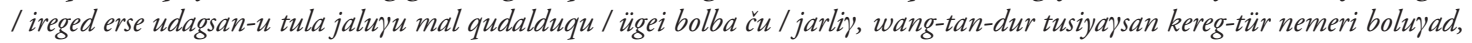

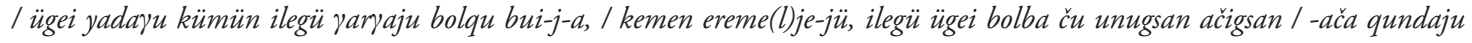

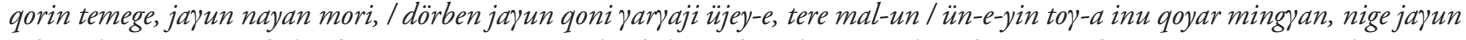

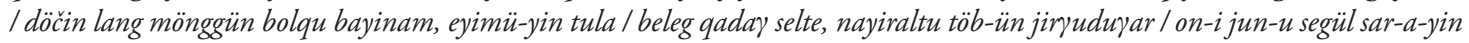
jiryujan-a dab / deger-e ergübe." NCA Mongolia, M10D3-6.1.

50. In Mongolian, joriztu means brave, and qosi $u_{u c i} i$ is a title for military commanders.

51. Ochiryn Oyunjargal, Manj Chin ulsaas mongolchuudyg zakhirsan bodlogo (Ulaanbaatar: Arvin sudar, 2009), 51-64. 
My conclusion is that instead of the banner of the Qošud Prince Abuu, which was in the Köke nayur region at this time (1724-1729), Mergen Tsorji's Torguds, neighbors of the other five banners in western Qalqa, were the Oyirad League's sixth banner from the beginning. As recorded in extant documents, the Torguds still considered themselves "people of the Torgud state" and tried to keep their distance from the Dzungars (in general, Manchu ület means Oyirad, but strictly it indicates the Dzungars ruled by the Coros lineage). After fifty years the history of the existence of an independent Torgud banner in western Qalqa was not common knowledge for the composers of the Biographies and Records of the Outer Mongolian and Muslim Princes and Dukes, leading them to include the later Alashan Qošuds, located at that time in the Köke nayur region, as a banner of the Oyirad League.

But why was almost nothing known about the Torgud jasay banner--which really existed-- after just fifty years? The Grand Council copies of Manchu-language archives held in Beijing provide an answer.

\section{The End of the Torgud jasay Banner-1731}

After the death of Dzungar leader Tsewang Rabtan in 1727, Galdan Tsering succeeded to the throne of his father and began to implement an active policy toward the Mongols of the Qing Empire. In the last winter month of the eighth year of Yongzheng (Jan. 8Feb. 6, 1731) General Furdan of the north army in Qalqa memorialized:

It is uncertain whether Dzungar thieves would attack the pasturelands of the Qalqa Prince Tongmok and Qoyid Prince Baji, passing through the posts of the Aji and Baji. I have ordered General Basai to collect about two thousand hand-picked troops and send them under the official Dengšou and commanders Marči and Raši to Köbger, to join the 1,300 Qalqa and Čaqar troops and then redeploy as a group to Lake Ikes. [I have] also ordered [him] to send Princes Geleg Yampil, Tongmok, and Daši Darja with one thousand troops to Dengšou to join him. And send two thousand troops under Commander Asan and Prince Dafu to Köbger for joint operations. ${ }^{52}$

In the following year, 1731, Dzungar forces passed the Altai Mountains, near Lake Khoton-nayur, destroyed one of the Qing armies, and eventually advanced deep into the Qalqa banners. In YZ 9/10 (Oct. 31-Nov. 28, 1731), Qing General Marsai reported:

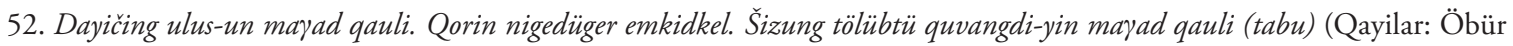

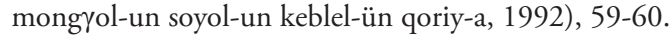


The commander of the twenty-ninth relay station, Dalai, reports: "Rebels have traversed the Nam dabayan Pass and entered the pastures of Biger čayan örge. [They have] attacked and captured Qoyid Prince Baji, disciples of the Torgud Gomang Lama, and Bandi of the Dzungar Prince Sebten Wangbu. Half of the rebel troops headed to the fortress of Godoli, passing through Siryayin yobi. One part of them headed to the Khangai Mountains and to the Tuul River. They wish to join each other near the monastery of Erdeni Juu and capture the pasture lands of Qalqa." 53

But soon afterwards, it became clear that Oyirads had not been captured but had defected to the enemy and were used by the latter as guides in the vanguard of the Dzungar army. A general, Prince Sibao, reported to the emperor based on the captives' testimony:

When both [elder and younger] Tsering Dondubs and Dorji Damba entered [our] territory with thirty thousand rebels, the Torgud Mergen Tsorji and Qoyid Prince Baji went over to the rebels with the people of their banners and directed them to join the banners of Princes Tongmok and Tsedenjab. ${ }^{54}$

Lama Lubsang Geleg, a subject of the Qoyid Prince Baji who would flee Dzungar captivity in the following year, told Qing officers that Mergen Tsorji's Torguds and Prince Baji's Qoyids had surrendered to the Dzungar army in YZ 9/9 (Oct. 1-30, 1731). ${ }^{55}$ In YZ 10/2/6 (Mar. 2, 1732) Qing border guards arrested the lamas Nawang Jamcu and Nawang Odzer, former subjects of Prince Pungcuk Daičing from the banner of Qalqa Prince Tongmok, who had been captured by the Dzungars the previous year. Then Prince Pungcuk Daičing was surrounded by 1,500 troops of the Dzungar Jaisang Haliun and was forced to surrender and submit to them. His men were left behind in Urunggu for the winter. The Qing generals memorialized:

When we asked Nawang Jamcu and others to tell all of what they had found out and heard, they answered: When the rebels resettled them to the place called Urunggu, they sent envoys together with the envoys of both [elder and younger] Tsering Dondubs. Our prince Pungcuk Daičing sent the man named Damba, Prince Baji sent the noble Ahai taiji, and Mergen Tsorji of the Torguds sent the man named Lubsang Širab. In the eleventh month (Nov. 29-Dec. 28, 1731) our envoys, headed by Damba, came back and reported as follows, "When we got in there we met with Galdan Tsering. Galdan Tsering

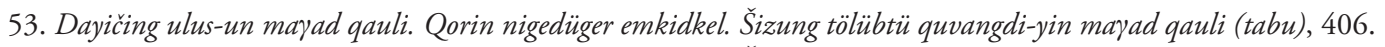

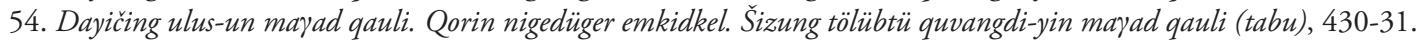

55. Junjichu Manwen lufu zouzhe 軍機處滿文錄副奏摺, First Historical Archives of China, Beijing, microfiche 25.000870. 
asked us, 'Who rules the seven banners of Qalqa, and who commands the Manchu and Mongol troops?' We answered that our seven banners of Qalqa are ruled by three men: Jasaktu Khan, Prince Danjin[dorji], and Prince Cecen (Tsering). All of the Manchu, Mongol, and Qalqa troops are commanded by the general prince (Tsering). ${ }^{56}$

The questioning of Dzungar refugee Bureči, a subject of Qoyid Prince Darjijab of the Dolot Otok, captured at the Qing-Dzungar border on YZ 10/2/3 (Feb. 28, 1732), revealed where exactly the defectors from the Qalqa had wintered.

Baji, Mergen Tsorji of the Torguds, and Jigjijab, who submitted to us, wintered in the places named Bula Chinggil and Hada Chinggil. Moohai and Tsering wintered in Uyengchi and Bodongchi. It is said that they will be moved far away to be involved in constructing fortifications. ${ }^{57}$

In the same year on 5/17 (June 9, 1732) a soldier named Jamcu came to the Qing border post in Aji from the left Tumed banner of Köke qota. He had been captured by the Dzungars in the battle of Lake Khoton nayur. At his interrogation he testified:

In the eleventh month, when both of the Tsering Dondubs came to Hada Chinggil with their troops, Abaldak sold me to the Torgud Mergen Tsorji for one camel. I spent the winter with Mergen Tsorji in Oola Ariktai. This year, when I found out that by 5/20 (June 12) the Torguds would be moved to Jair beyond the Erčis River, I fled on the night of 5/12 (June 4), riding one camel. Leaving Huwa Erčis, I went through the desert in the south and reached the Aji at the beginning of the intercalary fifth month. While I was there the subjects of the Torgud Mergen Tsorji were speaking: 'This year the elder Tsering Dondub is going to march with thirty thousand troops and reach the Kirang at least by $5 \mathrm{i} / 15$ (July 6). The younger Tsering Dondub will march to the Kazakh lands with twenty thousand troops. When the elder Tsering Dondub reaches the Kirang, they will feed their horses until they are heavy. Then they are going to attack the Qalqa pastures and take them.' I heard about it from the Torgud people,

56. "geli nawangjamcu sede, suweni donjiha, saha ele babe gemu ala seme fonjici, jaburengge, duleke aniya hülha membe gamafi urunggu bade isinaha manggi, meni taiji pungcuk daicing ni elcin damba, baji i elcin ahai taiji, turgüt $i$ mergen corji i elcin lubzang sirab ere ilan elcin be juwe ceringdondub sei takürara elcin i emgi k'aldan cering de taküraha bihe. omšon biyade meni taküraha elcin damba se amasi jifi alahangge, be genefi k'aldan cering de acaha. k'aldan cering, mende suweni kalkai nadan güsa be dalaha niyalma we, manju monggo cooha be uheri dalahangge we seme fonjiha, meni alahangge, meni kalkai nadan güsa be jasaktu han, danjin wang, cecen wang ere ilan dalahabi. manju, monggo, kalka uheri cooha be jiyanggiyün wang dalahabi seme alaha." Junjichu Manwen lufu zouzhe, microfiche 25.000839.

57. "mende dahaha baji, turgüt i mergen corji, jigjijab sebe bula cinggil, hada cinggil i jergi bade tuweri hetumbuhebi. moohai, cering sebe uyenci bodongci i jergi bade tuweri hetumbuhebi. esebe ere aniya casi nuktai baru guribufi usin bufi taribumbi sembi." Junjichu Manwen lufu zouzhe, microfiche 25.000691. 
who learned about it from the Dzungars. I saw the Jahacin people of the Dzungars, who were going to the place named Usun Ariktai with their families and children to cultivate the fields there, when they passed through Huwa Erčis. The subjects of Mergen Tsorji were also saying that Baji, who submitted to the rebels, said to Galdan Tsering: 'If [the emperor] plans to send a great army from the capital city (Beijing) this year, the army cannot easily come here on account of the distance. Even if they could reach here, their horses and cattle would be exhausted. So it would be better to send an army within the current year.' One hundred troops were drafted from the subjects of the Torgud Mergen Tsorji, levying one man from each household. Their women and children will be sent to Jair. The troops were drafted when I escaped from there. ${ }^{58}$

So the Torguds of Mergen Tsorji were moved into Emil Jair ${ }^{59}$ in mid-1732. On YZ 10/11/26 (Jan. 11, 1733), a runaway Qalqa named Yum arrived at the border post Haiči bulak from the banner of Tsering Wangčuk, having fled Dzungar captivity. He said:

The subjects of Prince Punsuk Daičing from the banner of our Qalqa Prince Tongmok and the subjects of Baji all live together now in the place called Kara Maili near Jair. Moohai was settled in Oola Ariktai and Gool Ariktai beyond the Altai Mountains. The people of Sebten Wangbu were divided among the tribes. The Torgud lama Mergen Tsorji was settled in Kara Ajirgan and Sira near the Jair. Among them, the Torgud lama Mergen Tsorji and Moohai have good relations with Galdan Tsering. When I fled, there were rumors that the people of Baji and our Qalqas would be divided like the Dzungars of Sebten Wangbu. ${ }^{60}$

58. "omšon biyade juwe ceringdondub cooha be gaifi hada cinggil $i$ bade isinaha manggi abaldak sere niyalma, turgüt i lama mergen corji ci emu temen gaifi mimbe uncaha. bi mergen corji be dahame oola ariktai i bade tuweri hetuhe. ere aniya sunja biyai orin de, turgüt $i$ urse ercis $i$ cala jair $i$ bade gurime genefi tembi serede, bi sunja biyai juwan juwe $i$ dobori emu temen yalufi, hüwa ercis $i$ baci tucifi, julergi gobi deri šurdeme yabufi anagan i sunja biyai ice de aji karun de isinjiha. bi tubade bihede turgüt $i$ mergen corji i fejergi ursei gisurehengge, ere aniya jun gar i nukte ci ilan tumen cooha tucibufi amba ceringdondub dalafi anagan $i$ sunja biyai tofohon de kirang ni bade isinjimbi. ajige ceringdondub juwe tumen cooha be tucibufi hasak $i$ ergide unggimbi. amba ceringdondub i gaifi jidere ilan tumen cooha kirang ni bade tefi morin be ujifi tarhüha erinde, tulergideri surdeme genefi, kalkasai nukte be necinjimbi seme turgüt i fejergi urse jun gar i niyalma ci donjifi, gisurere be bi donjiha, jai jun gar i jahacin urse usun ariktai de usin tarime jimbi seme ilan biyade hehe juse suwaliyame gurif, hüwa ercis deri tulere be sabuha. mergen corji $i$ urse geli gisurehengge hülha de dahaha baji, k'aldang cering de alahangge, ere aniya ging hecen ci amba cooha jici, jugün goro, ja de isiname muteraku, uthai jicibe, inu ulha macufi teni isinjici ojoro dabala, ubaci ere aniya be amcame cooha dosici sain seme jombume alaha sembi. geli turgüt $i$ mergen corji i fejergi ursei dorgici boigon tome emte haha be sonjome, uheri emu tanggü cooha tucibumbi, funcehe urse be ceni hehe juse i emgi jair $i$ bade guribumbi seme, mini jidere de cooha tucibumbihe seme alambi." Junjichu Manwen lufu zouzhe, microfiche 25.000598-605.

59. Zair is the name of a mountain, located at $45^{\circ} 9^{\prime} \mathrm{N}$ and $8^{\circ} \mathrm{E}$, on the border between the PRC and Kazakhstan, in the territory of Toli xian, Tarbagatay county, in the Xinjiang Uigur Autonomous region of the PRC. Radnabhadara, Zay-a Bandida, 83.

60. "jai duleke aniya tabcilabuha musei kalkai gung tongmok i güsai taiji punsuk daicing sei urse gemu baji i niyalmai sasa jair ba $i$ hanci kara maila $i$ bade tehebi, moohai be ini fejergi ursei sasa altai i cargi oola ariktai, gool ariktai $i$ bade tebuhebi. sebten wangbu i niyalma be ceni nukte de isiname gemu aiman aiman de facabume dendehe. turgüt $i$ lama mergen corji be jair ba $i$ hanci kara ajirgan, sira i jergi bade nukteme tebuhe. desei dorgide k'aldan cering kemuni turgüt i lama mergen corji, moohai be 
The Torguds ended their journey in Kara Ajirga and Sira near the Jair, where the Qoyids of Baji and the Qalqas of Pungcuk Daičing were also settled. Beginning with the Dzungar invasion in 1731, the banner ruler Jasay Prince Keirub is nowhere mentioned. Perhaps he had been long dead by that time. In this way, the Torgud banner, which actually came from the Volga region on the western frontier of Qing-ruled Qalqa, ended up near the Jair. At the same time the league of the Oyirads fell apart as a result of the Dzungar invasion of Qalqa.

Because the banner only existed for about three years and its population defected to the Dzungars from the Qing side, few documents survive. For that reason, there is no mention of this banner in Qing official historical works. The composers of the late Iledkel sastir mixed up Mergen Tsorji's group with the other Torguds under Arabjur, who also came from the Volga region. The biography of the banner prince Arabjur in the Iledkel sastir says:

Danjung, who initially inherited the title, was the elder son of Arabjur. He inherited the title of banner-beise. In the seventh year of the Yongzheng reign (1729) he had an imperial audience and was given the title of doroi-beile. In the ninth year (1731) the Dzungars sent spies to the Qalqas and Oyirads who had submitted. And they also sent troops in several directions to attack the pasturelands. Then a Danjung subject named Mergen Tsorji deserted to the Dzungars. ${ }^{61}$

The reason for such a mistake by the composers of Iledkel šastir likewise lies in the fact that the Torguds under Mergen Tsorji did not return to Qalqa after the conquest of Dzungar land in 1755, in contrast to the Qoyids of Baji and the Qalqas of Tongmok.

We do not know what happened to these Torguds later. We only know that in Joriytu Khan's banner of the Ünen Süjügtü old Torguds, there was a niru that consisted completely of Gümeng Gegen disciples. ${ }^{62}$ The latter's residence was located in the monastery of Balyanatai sir-a süme. This Gümeng Gegen qualified as the reincarnation of the Gomang Lama Dondub Gyatso. Maybe the so-called saabi (disciple) subjects of Gomang Lama fled to the Volga Kalmyks after the fall of Dzungar state in 1755 or even earlier. There is no reliable source for this event's details.

tuwarangge sain. mini jidere de donjici, baji i niyalma jai musei kalkasa be inu wang sebten wangbu i ület sei songkoi facabume niyalma de dendeme bure mejige bi sembi.” Junjichu Manwen lufu zouzhe, microfiche 25.000998.

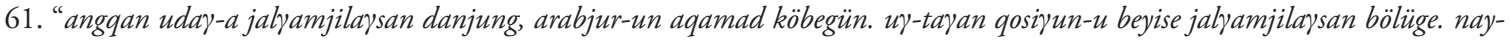

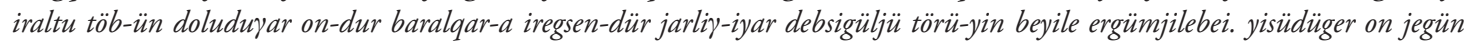

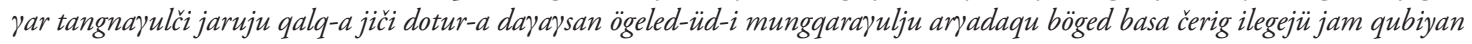

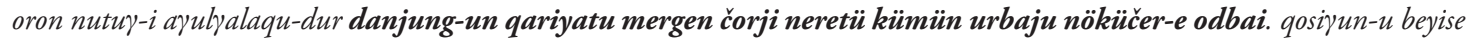

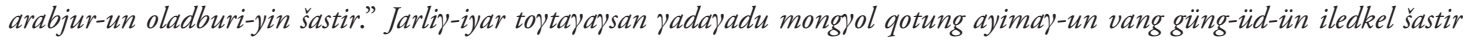
(dumdadu), 332-33.

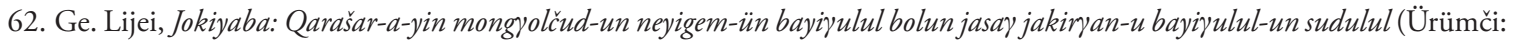
Sinjiyang-un arad-un keblel-ün qoriy-a, 2008), 162. 


\section{Conclusion}

From the above, one can see that Gomang Lama Dondub Gyatso from the VolgaKalmyk khanate was a remarkable person who played an active role on the Inner Asian political scene. Once sent by his remote relative Ayuki Khan, probably, on a diplomatic mission to the Dzungar leader Galdan Bošoytu Khan, he could not normalize the relations between the two Oyirad leaders. And after the usurpation of Tsewang Rabtan and after Galdan Bošo ytu Khan's heavy defeats by the Qing army in 1690, he started to represent his own small but strong domain between the two Dzungar leaders. After the death of Galdan Bošoytu Khan and facing the unification policy of the new Dzungar leader Tsewang Rabtan, Gomang Lama moved his sabi subjects to the northwestern region of Köke nayur. After longstanding conflicts with the Tibetan tribes of the SinoTibetan frontier who had submitted to the Qing, Gomang Lama, as the representative of the Dalai Lama's government, was ultimately forced to submit to the Qing. Those of his subjects ruled by his nephew Mergen Tsorji, living relative freely in the northwestern Köke nayur region, were forced to leave that area because of the Qošud Lubsang Danjin's uprising. Although the Qing military administration in Qalqa tried to incorporate them into one of the neighboring banners there, they were in the end organized into a separate banner ruled by a relative of Ayuki Khan on account of their silent resistance.

The organization of one more banner from the Torguds of the Kalmyk khanate in addition to the group of Arabjur, which, for several reasons, could not rejoin its brothers in the Volga region, was an excellent illustration of the special treatment shown by the Qing Empire to the Kalmyk khanate, a desirable ally against the Dzungar state. But the all-Oyirad identity of this group was stronger than the grace of the Manchu emperor, and during the Dzungar-Qing war the population of this new banner submitted to the Dzungar state, as did the other Oyirad banners of the Oyirad league in Western Qalqa. This was the main reason for late Qing official chroniclers' ignorance of this banner, which, in fact, existed for just three years. It shows once again the importance of Manchu- and Mongol-language primary documents for the study of the history of the non-Chinese territories of the Qing Empire.

\section{Bibliography}

\section{Archival sources}

Fuheng 傅恆 et al., compilers. Jun gar $i$ ba be necihiyeme toktobuha bodogon i bithei julergi banjibun. Ilaci debtelin. National Central Archives of Mongolia.

NCA M1D1 Khüreend suuj khereg shiitgegch manj saidyn yaam Хүрээнд сууж хэрэг шийтгэгч манж сайдын яам. National Central Archives of Mongolia, Ulaanbaatar. 
NCA M2D1 Uliastain manj janjny gazar Улиастайн манж жанжны газар. National Central Archives of Mongolia, Ulaanbaatar.

NCA M10D3 Tüsheet khan aimgiin tuslagch janjny jasaa Түшээт хан аймгийн туслагч жанжны жасаa. National Central Archives of Mongolia, Ulaanbaatar.

Junjichu Manwen lufu zouzhe 軍機處滿文錄副奏摺. First Historical Archives of China, Beijing.

Kangxi chao Manwen zhupi zouzhe康熙朝満文朱批奏折. First Historical Archives of China, Beijing.

\section{Published sources}

A $\gamma$ vanglhüngdübdarji and Lubsangtübdenjamčo. Jiryuduүar dalai blam-a-yin namtar qoyar jüyil. Translated by Jamyangdampelnim-a. Köke qota: Öbür mongyol-un arad-un keblel-ün qoriy-a, 1999.

Badai, Altanorgil, and Erdeni. Oyirad teüke-yin durasqal-ud. Ürümči: Sinjiyang-un arad-un keblel-ün qoriy-a, 1992.

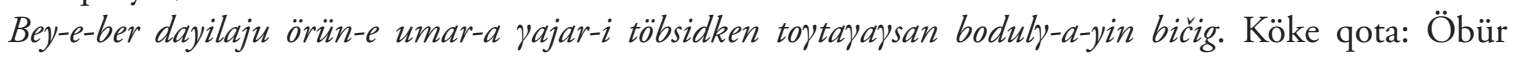
mongyol-un soyol-un keblel-ün qoriy-a, 1992.

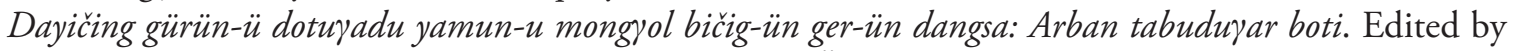

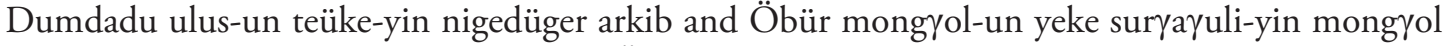

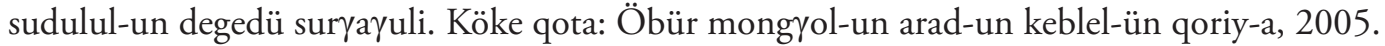

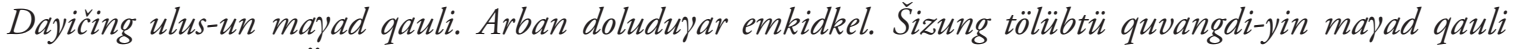
(nige). Qayilar: Öbür mongyol-un soyol-un keblel-ün qoriy-a, 1992.

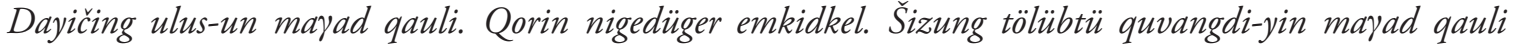
(tabu). Qayilar: Öbür mongyol-un soyol-un keblel-ün qoriy-a, 1992.

Gonchok Jigmed Wangbo. Povestvovanie o žizni Vsevedushego Žamjan-Šadby "Brod vedušij k udivitel’no blagomu udelu." Translated with commentary by Nikolai Tsyrempilov. Ulan-Ude: Izdatel'stvo BNC, 2008.

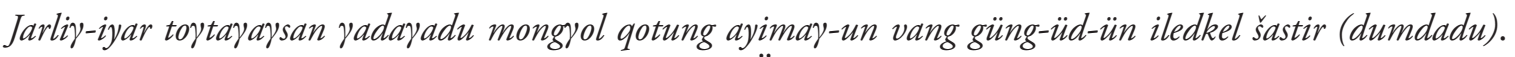

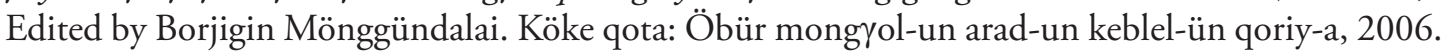

Lijei, Ge. Oyirad-un teüke šasin-u sudulul. Ürümči: Sinjiyang-un arad-un keblel-ün qoriy-a, 2002.

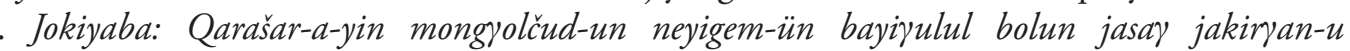
bayijulul-un sudulul. Ürümči: Sinjiyang-un arad-un keblel-ün qoriy-a, 2008.

Miyawaki, Junko. "Examples of the Archival materials on Mongol History Existing outside of Mongolia." In Researching Archival Documents on Mongolian History: Observations on the Present and Plans for the Future, pp. 165-200. Tokyo: Tokyo University of Foreign Studies, 2004.

Oyunjargal Ochiryn. Manj Chin ulsaas mongolchuudyg zakhirsan bodlogo. Ulaanbaatar: Arvin sudar, 2009.

Radnabhadara. Zay-a Bandida. Commentary by Si. Norbu. Köke qota: Öbür mongyol-un arad-un keblel-ün qoriy-a, 1999.

Sükhbaatar Na. Oirad mongolyn tü̈̈khend kholbogdokh survalj bichgü̈̈d III. Ulaanbaatar: Soyombo, 2002.

Tepkeev V. T. "XVII zuuny süüleer Orosyn ömnöd khesegt Züüngaryn ööldüüd irj nutaglasan ni.” Historia Mongolarum 13, no. 397.34 (2014): 16-27.

Terbish Lkhasrangiin. Oiradyn burkhny shashny tovch tuukh. Bibliotheca Oiratica XI. Ulaanbaatar: Soyombo, 2008.

Tugan Luwsanchoijinyam. Boloryn toli. Ulaanbaatar: Admon, 2006.

Veit, Veronika. "Galdan's Nephew Danjila (d. 1708): An Example of the K'ang-hsi Emperor's Successful Policy towards the Mongols." Asian and African Studies 16.3 (1982): 345-56

Wang, Xiuyu. China's Last Imperial Frontier: Late Qing Expansion in Sichuan's Tibetan Borderlands. Lanham, Md.: Lexington, 2011. 
Wu, Shuhui. Die Eroberung von Qinghai unter Berücksichtigung von Tibet und Khams 1717-1727: Anhand der Throneingaben des Grossfeldherrn Nian Gengyao. Wiesbaden: Harrasowitz, 1995.

Zhongguo diyi lishi dang'anguan 中国第一历史档案馆et al., editors. Yongzheng chao Manwen zhupi quanyi 雍正朝满文朱批全译. Beijing: Huangshan shushe, 1998. 